\title{
Analysis of changes in composition of amber with ageing using pyrolysis/GC/MS
}

\author{
Jongseo Park ${ }^{\star}$ \\ Research Division of Restoration Technology, National Research Institute of Cultural Heritage, \\ 132 Munji-ro, Yuseong-gu, Daejeon 305-380, Korea \\ (Received April 30, 2012; Revised June 12, 2013; Accepted June 12, 2013)
}

\section{열분해/GC/MS를 이용한 열화 호박(amber)의 성분 변화 분석 \\ 박 종 서` \\ 국립문화재연구소 복원기술연구실 \\ (2012. 4. 30. 접수, 2013. 6. 12. 수정, 2013. 6. 12. 승인)}

\begin{abstract}
Ambers have been used mostly as beads, jewelry and ornaments from ancient times and excavated as a buried artifact. When excavated, they are severely weathered to be cracked, exfoliated and disintegrated. Monitoring of changes in composition of amber according to weathering is very important for diagnosing the condition of amber and applying conservation materials and techniques. In this study, we tried to find the components of amber by analyzing amber with pyrolysis/GC/MS. The changes in the composition of pyrolzates after artificial ageing for 60 days under heat and oxygen were also observed. Abietic acid was detected as a main component of fresh amber and monoterpene, alkene, aromatic hydrocarbon were detected as major pyrolyzates. Changes with artificial ageing was estimated by comparing the peak area ratio of 23 components, and it was found that abietic acid abruptly decreased in the presence of heat and oxygen together, revealing that oxygen is a key factor to the deterioration of amber. It was also tried to understand the weathered surface of original amber gemstone based on the result of this ageing experiment.

요 약: 호박은 오래전부터 장식품, 공예품, 부장품 등으로 사용되어 매장문화재 형태로 발굴되고 있다. 발굴 당시 호박은 풍화가 많이 진행되어 표면의 균열, 박락 등이 관찰된다. 풍화에 따른 호박의 성분 변 화를 파악하는 것은 보존상태를 진단하고, 적절한 보존방법을 적용하는데 있어 매우 중요하다. 본 연구 에서는 열분해/GC/MS로 호박의 열분해 산물을 분석하여 호박을 구성하는 성분을 찾고자 하였다. 또한, 열과 산소가 있는 조건에서 60 일 동안 인공열화하여 호박의 열분해 산물의 구성비가 변화하는 것을 관 찰하였다. 실험결과 호박의 주요 열분해 산물로 abietic acid가 검출되었고, monoterpene류, alkene류, aromatic hydrocarbon류가 검출되었다. 주요한 23 개의 성분에 대해 열화에 따른 상대적인 면적비를 비교 하여 열화에 따른 경향성을 파악하였다. 주성분인 abietic acid는 산소와 열이 있는 조건에서 급격하게 감 소하였지만, 열만 있는 조건에서는 변화가 크지 않은 것으로 보아 산소가 호박의 열화에 중요한 역할을 하는 것으로 판단된다. 실제 풍화된 호박 원석의 표면에 대해 열화실험 결과를 적용하여 열화상태를 파 악하는 시도도 하였다.
\end{abstract}

Key words: amber, py/GC/MS, artificial ageing, composition

Corresponding author

Phone : +82-(0)42-860-9342 Fax : +82-(0)42-861-5168

E-mail : jongseo71@korea.kr 


\section{1. 서 론}

호박은 삼나무과, 금송과, 콩과 등의 나무에서 나오 는 삼출물이 수백만년 동안 땅 속에 묻혀 고분자화된 것으로서 Baltic, Dominican 호박 등 생성된 장소에 따라 다양하게 존재한다. 옛날부터 광택, 희소성 등 보석으로서의 특성을 가지고 있어 장식품, 공예품 등 에 사용되어 왔다. 우리나라에서도 백제, 가야, 신라 등 삼국시대 이래 유적에서 호박유물이 종종 출토되 어 왔으며, 조선시대에 사용된 호박 장식품은 상당수 가 전세되어 오고 있다. ${ }^{1}$ 호박은 화학적으로 communic acid, abietic acid, pimaric acid 등 diterpenoid 계열에 속하는 물질들의 라디칼 반응에 의한 고분자화에 의 해 생성된다. 수천년 동안 일어나는 부분 고분자화 과 정을 거쳐 copal이 생성되며, 이후 수백만년 동안 휘 발성 terpene이 증발해 호박을 형성한다. 호박의 주요 특징을 Table 1에 나타냈다.

식물성 수지는 매우 복잡하고 다양한 성분들의 혼 합물로서 terpenoid 수지와 phenolic 수지의 2가지 그 룹으로 분류가 가능하다. Terpenoid 수지는 isoprene 단위 $\left(\mathrm{C}_{5} \mathrm{H}_{8}\right)$ 로 구성되며, fused ring system을 구성하고, 침엽수와 속씨식물에 널리 존재한다. 여러 성분 중 diterpenoid $\left(\mathrm{C}_{20}\right)$ 와 triterpenoid $\left(\mathrm{C}_{30}\right)$ 가 화석화하여 호 박이 된다. ${ }^{3}$ Diterpenoid는 2 가지 주요 그룹으로 분류 될 수 있다. 매우 반응성이 강한 불포화 $\mathrm{C}_{6}$ side chain 을 가지는 bicyclic molecule인 labdane 유도체로서 trans-commuci acid, agathic acid, agatholic acid, acetoxyagatholic acid, larixol, larixol acetate 등이 있다. Tricyclic acid가 있는 pimarane과 abietane류에는 pimaric acid, sandaracopimaric acid, isopimaric acid, abietic acid, dehydroabietic acid, 7-oxo-hydroxydehydroabietic acid 등이 있다. Triterpenoid계열의 천연수지는 dam-

Table 1. A small summary of the general chemical and physical properties of amber ${ }^{2}$

\begin{tabular}{|c|c|}
\hline Elementary composition & $\begin{array}{l}\text { C: } 61-81 \%, \mathrm{H}: 8.5-11 \%, \mathrm{O}: 15 \% \text {, } \\
\text { S: } \sim 0.5 \%, \mathrm{Fe}: \sim 0.2 \%\end{array}$ \\
\hline Hardness & $\begin{array}{l}199-290 \mathrm{MPa} \text { or } 2.0-2.5 \text { on Mohs } \\
\text { scale }\end{array}$ \\
\hline Density & $0.96-1.096 \mathrm{~g} / \mathrm{cm}^{3}$ \\
\hline Melting temperature & $287-300{ }^{\circ} \mathrm{C}$ \\
\hline $\begin{array}{l}\text { Light refraction } \\
\text { coefficient }\end{array}$ & $1.539-1.542$ \\
\hline Other optical properties & $\begin{array}{l}\text { Fluorescence, UV transparence, } \\
\text { anomalous birefringence }\end{array}$ \\
\hline
\end{tabular}

marane, lanostane, oleane, ursane 골격을 가지는 화합물 이며, dammaradienone, hydroxydammarenone, dammarenolic acid, oleanolic aldehyde, oleanonic acid, moronic acid, ursonic aldehyde, ursonic acid, masticadienonic acid 등이 이에 해당한다. ${ }^{4}$ Baltic 호박은 가교결합이 있는 고 분자로서 다가 알콜과 dibasic acid의 에스테르화반응의 산물이다. 다가 알콜은 communal과 communic acid의 공중합체이고 dibasic acid는 succinic acid이다..$^{5}$ 하지만, succinic acid가 호박의 원래성분이 아니라 abietic acid의 분해산물이라는 주장도 있다. 에스테르화 과정은 다른 고분자 사이의 가교결합을 도입해 분자량을 증가시키 고, 구조를 단단하게 하며, 용해도를 떨어뜨린다. Baltic 호박은 고분자물질 외에 borneol, camphor, fenchyl alcohol, fenchone과 같은 monoterpene과 aromatic hydrocarbon을 포함한다. ${ }^{5}$ 호박의 주요 성분으로 알려진 abietic acid, communic acid, succinic acid의 분자구조를 Fig. 1에 나타냈다.

이러한 고분자 수지의 분석은 용해도와 분자량 등의 문제점 때문에 열분해/GC/MS가 가장 적합한 분석 방 법이다. 열분해/GC/MS는 고분자 물질의 분석을 포함한 다양한 분야의 응용에 있어 간단하고, 빠르고, 신뢰성 있는 분석기술로 정립되어 왔다. ${ }^{6}$ 열분해/GC/MS분석에 는 적합한 시료 전처리 방법이 필요한데, 시료의 특성 에 따라 간단한 가수분해, 용해 단계를 필요로 하거나 복잡한 유도체화 과정을 필요로 하기도 한다. 유도체화 방법으로는 hydrogenation, methylation, silylation 등이 있으며, 이를 통해 분해산물의 휘발성을 높여 GC/MS 분석을 용이하게 해 준다. 가장 흔하게 사용되는 유도 체 시약은 tetramethylammonium hydroxide로서 on-line 으로 thermally assisted hydrolysis와 methylation이 가능 하다. 이 방법은 빠른속도, 감도, 샘플량, 전처리, 비용 면에서 장점을 가진다. HMDS(hexamethyldisilazane)를 이용한 on-line 유도체화도 사용되는데, 열분해 산물을 trimethylsilylation시킨다. HMDS를 유도체화 시약으로 사용했을 때 감도와 분해능에 있어 더 향상된 크로마 토그램을 얻을 수 있다는 보고도 있다.,8 문화재에 사 용된 접착제, 페인트, 색소, 결착제, 광택제 등의 분석 은 보존과 복원 작업을 원활하게 수행하는데 있어 매 우 중요한 정보를 제공하며, 제작기술의 추정에도 도움 이 된다. 하지만, 이들을 녹이는 적절한 용매가 없는 경 우가 많고, 용매가 있다 하더라도 고분자 물질이기 때 문에 화학성분을 규명하는데 어려움이 있다. 열분해/ $\mathrm{GC} / \mathrm{MS}$ 는 수 $\mathrm{mg}$ 단위 소량의 시료로 열분해 산물의 화학성분을 찾을 수 있고, 그 결과로부터 원래 고분자

Vol. 26, No. 3, 2013 
물질의 종류와 상태를 알 수 있기 때문에 문화재와 예술품의 분석에 도입이 되었다. 아교와 같은 단백질 결착제(binder), 칠이나 동유와 같은 비단백질성 결착 제의 특성을 열분해/GC/MS를 통해 규명하려는 연구 가 있었으며, ${ }^{9}$ 꼭두서니(madder), 삼황(curcuma), saffron, indigo와 같은 천연 염료 ${ }^{10}$ 와 밀랍 조각품의 특성 분석 도 열분해/GC/MS방법으로 가능하다. ${ }^{11}$

식물성 고분자 수지에서 생성된 호박의 풍화에 따 른 변화를 관찰하는 방법은 IR, Raman, 형광 분석법 등 주로 비파괴적인 방법이다. 이는 호박이 출토유물 로서 문화재에 해당하는 경우가 대부분이어서 파괴적 인 방법을 채택하기 어렵기 때문이다. 파편의 획득이 가능한 경우에 열분해/ $\mathrm{GC} / \mathrm{MS}$ 분석, $\mathrm{GC} / \mathrm{MS}$ 분석, 용해 도 분석, 열분석 등을 통해 호박의 특성을 파악하기 위한 노력도 있었다. 하지만, 호박을 통제된 조건에서 인공적으로 열화하여 그것의 성분변화를 관찰한 예는 드물다. 본 연구에서는 호박의 구성 성분을 파악하기 위해 열분해/GC/MS 분석을 실시하였다. 또한, 호박을 열 조건, 열과 산소 조건에서 60 일 동안 인공열화시킨 후 열분해/GC/MS분석을 실시하여 호박 구성 성분과 열분해 산물의 변화양상을 관찰하였다. 구성 성분에 대한 상대적인 변화와 주요 성분의 시간에 따른 변화 를 파악하였으며, 이를 토대로 호박의 상태를 진단할 수 있는 마커를 선정하고자 하였다. 아울러, 이 결과 를 실제 호박의 풍화된 표면에 적용하여 풍화정도를 이해하려는 시도를 하였다.

\section{2. 실 험}

\section{1. 시료}

실험에 사용한 호박은 Baltic 호박으로 웹사이트를 통해 구매하였고 IR 분석과 Raman분석 후 기 발표된 논문자료와 비교하여 산지에 대한 신뢰성을 확보하였 다. ${ }^{12-14}$ 시료의 균질성을 확보하기 위해 원석에서 자연 풍화된 부분을 제거한 후 그 내부를 사용하였다. 시료

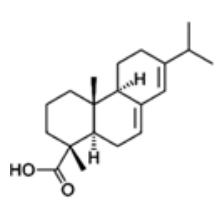

(a)

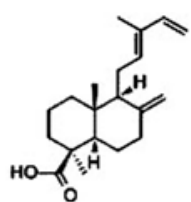

(b)

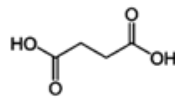

(c)
Fig. 1. Molecular structure of compounds constituting an amber. (a) abietic acid, (b) communic acid, (c) succinic acid

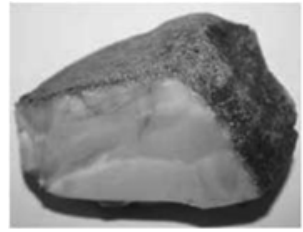

(a)

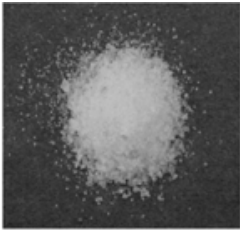

(b)
Fig. 2. Photographs of raw Baltic amber (a) and its crushed powder (b).

는 마노사발(Agate mortar \& pestle)에서 수작업으로 가루를 만들어 사용하였는데, 실험에 사용한 호박 원 석과 분쇄 후 호박 시료를 Fig. 2에 나타냈다.

\section{2. 장비 및 분석절차}

Pyrolyzer는 Frontier Lab 사의 PY-2020iD 모델을, GC/ $\mathrm{MS}$ 는 Agilent 사의 6890GC/5973MSD 모델을 사용하였 다. 유도체화 시약인 HMDS (hexamethyldisilazane, ReagentPlus ${ }^{\circledR}, 99.9 \%$ )는 Sigma-Aldrich에서 구입하였으 며, 구입한 대로 사용하였다. 열분해/GC/MS 분석은 약 $2 \mathrm{mg}$ 의 시료를 quartz tube에 담고 약 $10 \mu \mathrm{L}$ 의 유도체 화 시약을 적가한 후 미리 가열되어 있는 열분해장치 속에 삽입하여 수행하였다. 열분해는 $300{ }^{\circ} \mathrm{C}$ 에서 1 분간 수행하였고, $\mathrm{GC} / \mathrm{MS}$ 분석조건은 다음과 같다.

- Column : ZB-5HT column (5\% phenyl-95\% dimethylpolysiloxane, $30 \mathrm{~m} \times 0.25 \mathrm{~mm}$ id, $0.25 \mu \mathrm{m}$ film thickness)

- Chromatographic condition : $50{ }^{\circ} \mathrm{C}$ isothermal for 1 min, $10{ }^{\circ} \mathrm{C} / \mathrm{min}$ up to $320{ }^{\circ} \mathrm{C}$ and isothermal for $5 \mathrm{~min}$ (a total of $33 \mathrm{~min}$ )

- Carrier gas : He at $1.0 \mathrm{~mL} / \mathrm{min}$

- MS transfer line temp. : $280{ }^{\circ} \mathrm{C}$, MS ion source temp. : $230{ }^{\circ} \mathrm{C}$, MS quadrupole temp. : $150{ }^{\circ} \mathrm{C}$

\section{3. 열화실험}

열화인자로 열, 산소를 선정하여 다음과 같이 열화 실험을 수행하였다.

\subsection{1. 열에 의한 열화}

분쇄한 Baltic 호박시료를 $90{ }^{\circ} \mathrm{C}$ 의 항온항습조(JEIO TECH TH-PE-100, Korea)에서 60일 동안 열화시켰다. 유리 vial (약 $2 \mathrm{~mL}$ )에 분말 형태의 시료를 담고 뚜껑을 닫지 않은 상태로 광구병 $(100 \mathrm{~mL})$ 에 넣은 후 광구병 뚜 껑을 살짝 닫아 다시 Tedlar bag $(1 \mathrm{~L})$ 에 넣었다. Tedlar bag에 진공을 걸어 공기를 뺀 후 질소를 충전한 다음 광 
구병의 뚜껑을 단단히 닫아 외부 산소의 영향을 최대한 제거하였다. 또한 빛의 영향을 제거하기 위해 항온항습 조 내부의 조명을 소등하였다. 이 때 항온항습조 내부의 습도는 5 8\%였다. 열화가 시작된 후 각 각 $5,15,30,60$ 일이 경과한 때 호박시료를 꺼내어 분석에 사용하였다.

\subsection{2. 산소에 의한 열화}

상온에서 산소에 의한 열화는 매우 미미했으므로 열 과 산소가 동시에 존재하는 조건에서 호박의 열화를 실시하였다. 실험 조건은 질소 대신 산소를 주입하여 산소조건을 구현한 것을 제외하고 열에 의한 열화 실 험과 동일하다. 열화가 시작된 후 각 각 $5,15,30,60$ 일 이 경과한 때 호박시료를 꺼내어 분석에 사용하였다.

\section{3. 결과 및 고찰}

\subsection{Baltic 호박의 열분해/GC/MS 크로마토그램}

Fig. 3에 Baltic 호박의 열분해/GC/MS 크로마토그

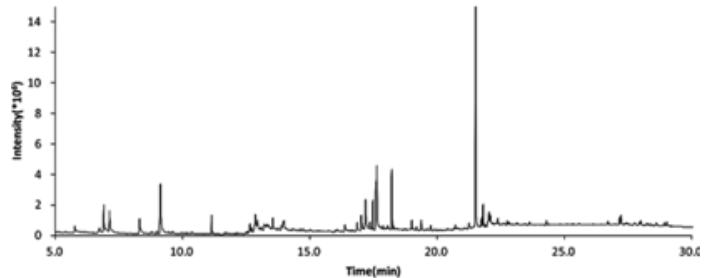

Fig. 3. py/GC/MS chromatogram of fresh Baltic amber.

램을 나타내었고, 주요하고 잘 정의된 peak을 선택하 여 library searching과 mass spectrum 검토를 하여 peak assign을 실시하였다(Table 2). 또한, 선택된 peak 면적 총합에 대해 각 peak가 차지하는 면적의 비율을 구하였다. 5 20분에 monoterpenoid와 sesquiterpenoid 가 나오고 이후 diterpeonoid acid가 검출되고 있다. Baltic 호박의 구성 성분으로 알려진 abietic acid의 $\mathrm{TMS}$ 유도체가 $83.2 \%$ 로 큰 비중을 차지하고 있으며, butanedioic acid(succinic acid)도 $1.6 \%$ 정도 비중을

Table 2. Compounds in the total ion chromatogram of the amber sample pyrolyzed in the presence of HMDS (Identification based on library matching)

\begin{tabular}{|c|c|c|c|c|}
\hline No. & r.t.(min) & compound & $\begin{array}{c}\text { Area ratio } \\
(\%)\end{array}$ & $\begin{array}{l}\text { RSD } \\
(\%)^{a}\end{array}$ \\
\hline 1 & 5.421 & tricyclene & $<0.1$ & 9.1 \\
\hline 2 & 5.819 & camphene & 0.4 & 3.1 \\
\hline 3 & 6.757 & 1-metheyl-2-(1-methylethyl)benzene & 0.6 & 10.9 \\
\hline 4 & 6.947 & limonene & 1.3 & 6.6 \\
\hline 5 & 7.167 & benzene derivative & 1.4 & 11.6 \\
\hline 6 & 7.943 & fenchone & $<0.1$ & 21.5 \\
\hline 7 & 8.329 & fenchyl alcohol & 0.7 & 11.7 \\
\hline 8 & 8.836 & camphor & 0.2 & 19.6 \\
\hline 9 & 9.158 & borneol & 2.0 & 6.8 \\
\hline 10 & 11.183 & butanedioic acid, bis(trimethylsilyl) ester & 1.6 & 27.2 \\
\hline 11 & 13.584 & 1,2,3,4-tetrahydro-1,1,6-trimethylnaphthalene & 0.7 & 7.2 \\
\hline 12 & 15.038 & $1,2,3,4,5,6,7,8$-octahydroanthracene & 0.5 & 13.1 \\
\hline 13 & 15.755 & $*$ & 0.6 & 13.8 \\
\hline 14 & 16.418 & 1,3-dimethyl-5-methylbenzene derivative & $<0.1$ & 24.1 \\
\hline 15 & 16.886 & 1,1,3,5-tetramethyl-3-neopentyl-2,3-dihydroindene & $<0.1$ & 2.3 \\
\hline 16 & 17.057 & 9-dodecyltetradecahydrophenanthrene derivative & $<0.1$ & 12.0 \\
\hline 17 & 17.392 & 1,1,3,3-tetramethyl-1,3,5-trisilacyclohexane & 0.8 & 3.4 \\
\hline 18 & 17.512 & $*(\mathrm{~m} / \mathrm{z}=173)$ & 1.5 & 5.9 \\
\hline 19 & 18.256 & 5-phenoxyvaleric acid, trimethylsilyl ester & 3.2 & 7.1 \\
\hline 20 & 19.034 & 1,4a.beta.-dimethyl-7-isopropyl-1,2,3,4,4a,9,10,10a.alpha.-octahydrophenanthrene & 0.5 & 7.3 \\
\hline 21 & 19.400 & 4b,5,6,7,8,8a,9,10-octahydro-4b,8-dimethyl-2-isopropylphenanthrene & 0.6 & 13.3 \\
\hline 22 & 19.774 & 1,2,3,4,4a,9,10,10a-octahydro-1,1,4a-trimethyl-7-(1-methylethyl)-,(4aS-trans)phenanthrene & 0.4 & 6.7 \\
\hline 23 & 21.543 & abietic acid, trimethylsilyl ester & 83.2 & 8.6 \\
\hline
\end{tabular}

*denotes 'not identified'.

aSD $(\%)$ means relative standard deviation.

Vol. 26, No. 3, 2013 
succinite라고 부르게 된 근거가 되는 물질로서 다른 산지의 호박에서는 검출되지 않은 Baltic 호박만의 특 성이다. ${ }^{15}$ Valeric acid, borneol, benzene, limonene 등이 $1 \%$ 이상의 점유율을 보이고 있으며, camphor, fenchyl alcohol, fenchone과 같은 monoterpene도 함께 검출되 고 있다. 또한, benzene, naphthalene, anthracene, phenanthrene과 같이 aromatic hydrocarbon류도 주요 한 성분으로 검출되었다. 분석의 재현성을 확인하기 위해 동일 시료에 대해 3회 반복측정을 실시하였고, peak 면적에 대한 상대표준편차(RSD, \%)를 Table 2에 표시하였다. 반복측정 결과 peak면적이 적은 경우 $\mathrm{RSD}$ 가 $10 \%$ 이상인 경우도 있으나, 대체로 $10 \%$ 이하 로 열화에 따른 경향성을 파악하는데 문제가 없을 것 으로 판단되어 이후 실험에서는 1 회의 분석결과를 데 이터로 사용하였다.

\section{2. 열화에 따른 열분해 산물의 변화}

Fig. 4에 신선한 호박의 크로마토그램, 열 열화조건 에서 $5,15,30,60$ 일 열화시킨 호박의 크로마토그램, 산소 조건에서 $5,15,30,60$ 일 열화시킨 호박의 크로 마토그램을 나타냈다. 우선, 열화 호박을 눈으로 관찰 했을 때, 열 열화에서 호박의 색깔이 황색이 짙어지는
정도로 색깔 변화가 적은 반면, 산소열화에서는 명도 값이 크게 감소하였고, 색깔도 붉은색과 청색의 특성 이 강해져 60 일 열화가 진행됐을 때는 검은색에 가깝 게 변해 있었다. 산소가 호박의 열화에 큰 영향을 미 침을 시각적으로 확인할 수 있었다. 하지만, 열화기간 내내 열분해/GC/MS 크로마토그램이 대체적으로 신선 한 호박에서 관찰되는 성분을 보여주고 있어 열화가 진행되더라도 호박의 기본적인 성분은 보유하고 있는 것으로 판단되었다. 이는 자연적으로 풍화된 실제 시 료에서 호박임을 확인하고, 호박의 산지 추정 가능성 도 있음을 의미한다.

고분자 수지의 열분해 산물의 정량은 그 수와 양이 광범위하기 때문에 매우 난해한 부분이다. 시료의 양 이 다르고 시료에 함유된 유기물의 양이 차이가 있기 때문에 피크 면적 자체는 신뢰도가 떨어진다. 따라서, 이를 해결하기 위해 정규화방법이 사용되는데, 크로마 토그램에서 해당 성분을 가장 큰 피크로 나누어 정규 화하는 방법, ${ }^{16}$ 크로마토그램에 공통으로 존재하는 피 크에 대한 비율을 구하는 방법, ${ }^{17}$ 주요한 피크의 총합 으로 나누는 방법 ${ }^{18}$ 등이 있다. 본 논문에서는 앞에서 선정한 23 개 성분에 대하여 그 총합에 대한 비율 변 화를 통해 시료량 차이에서 오는 peak의 면적 차이와

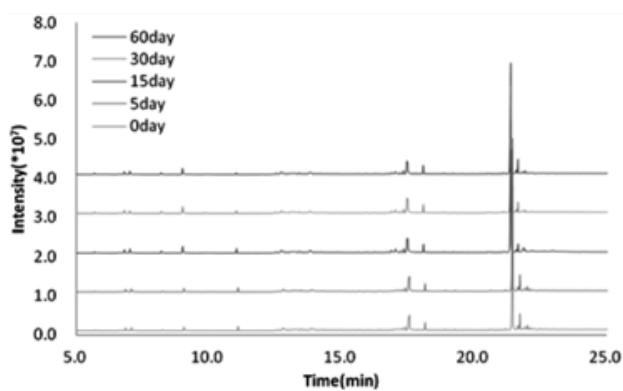

(a)

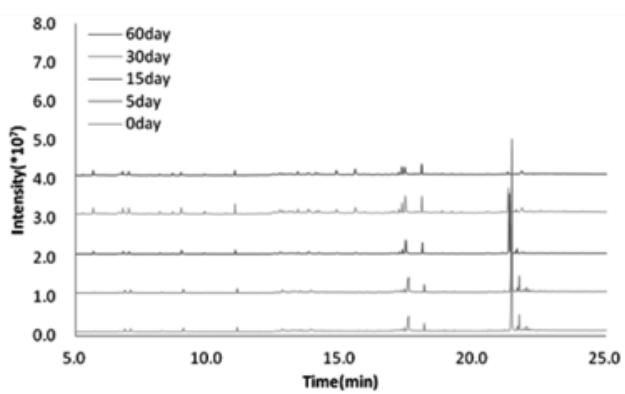

(b)

Fig. 4. py/GC/MS chromatograms of artificially aged amber: (a) under heat, (b) under oxygen and heat.

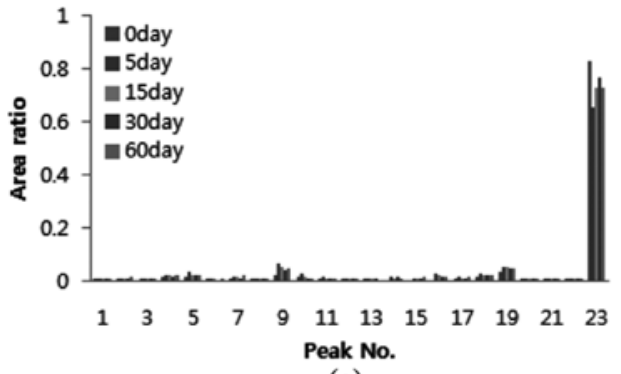

(a)

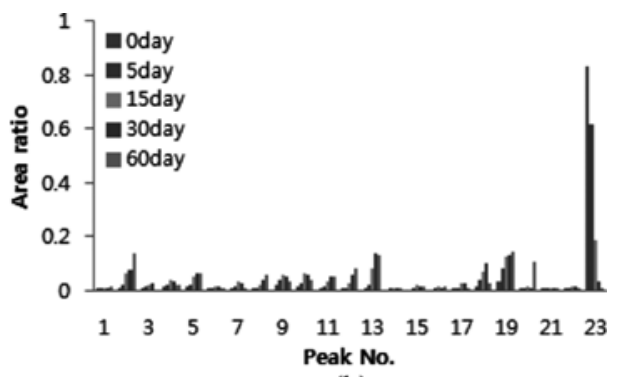

(b)

Fig. 5. Changes in composition with artificial ageing: (a) under heat, (b) under heat and oxygen. 
열분해 조건의 변동에 따른 peak의 면적차이를 보정 하고, 그 값을 열화에 따른 성분변화에 사용하였다. 아울러, 개별 성분 상호간의 면적비 변화도 살펴 보았 다. Fig. 5에 열 열화와 산소열화 시 peak 면적 총합 에 대한 각 peak의 면적변화를 열화시간에 따라 플랏 하였다.

우선 열 열화의 경우 peak 면적 총합에 대해서는 3 (1-metheyl-2-(1-methylethyl)benzene)과 10 (butanedioic acid)이 꾸준하게 감소하는 경향을 보였고, 나머지 성 분들은 일정한 경향이 없었다. 특히, butanedioic acid 가 감소하는 것은 특이한 현상으로 이해되며, 산소가 없는 상황에서 이 물질의 생성 없이 분해가 지속되거 나 다른 성분들의 생성만 일어나는 것으로 이해할 수 있다. 산소열화의 경우 다양한 성분에서 경향성이 나타 나고 있는데, 1 (tricyclene), 2 (camphene), 5 (benzene류), 8 (camphor), 11 (naphthalene류), 12 (anthracene류), 19 (5phenoxyvaleric acid)가 열화가 진행되면서 증가하고 있다. 호박의 대부분을 구성하고 있는 23(abietic acid) 은 열화시간이 증가하면서 그 양이 급격하게 감소하 고 있는 것으로 나타났다. 따라서, 이들 성분들의 peak 면적 총합에 대한 비율을 구할 경우 실제 호박시 료에서 열화가 인공열화의 며칠 째에 해당하는지 추 정하는 것이 가능할 것으로 생각된다. 호박의 또 다른 주요 성분인 10 (butanedioic acid)은 열화 15 일까지 증 가하다 그 이후 감소하는 것으로 나타났다.

한편, 개별 성분 상호간의 면적비를 열화시간에 대 해 플랏함으로써 열화가 진행됨에 따른 성분 변화 경 향을 파악하고 열화를 지시하는 간단한 마커 조합을 찾고자 하였다. Fig. 6(a)에 peak 1에 대한 기타 peak 면적의 열화시간에 대한 변화를 나타냈다. 동일한 방 법으로 모든 peak에 대해 면적비 변화를 구했으며, 그 결과를 Fig. 6(b)에 나타냈다. 여기서 '열화시 증가(A)' 로 표시된 조합은 열화에 따라 그 비율이 지속적으로 증가하는 조합을 말하고, '열화시 감소 $(\nabla)$ '는 그 반대 를 의미하며 빈 칸은 경향성이 없음을 의미한다. 열 열화에서 10 (butanedioic acid)은 peak 면적 총합에 대 해 지속적으로 감소하였는데, 개별 성분과 비교를 했 을 때 1 (tricyclene), 2 (camphene), 7 (fenchyl alcohol), 8 (camphor), 9 (borneol), 14 (1,3-dimethyl-5-methylbenzene 류), 15 (1,1,3,5-tetramethyl-3-neopentyl-2,3-dihydroindene), 16 (9-dodecyltetradecahydrophenanthrene 류), 17 (1,1,3,3tetramethyl-1,3,5-trisilacyclohexane), 22 (1,2,3,4,4a,9,10, 10a-octahydro-1,1,4a-trimethyl-7-(1-methylethyl)-, , (4aStrans)-phenanthrene)에 대해 감소하는 것으로 나타났다.

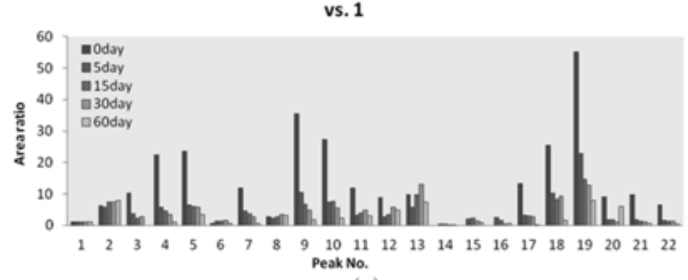

(a)

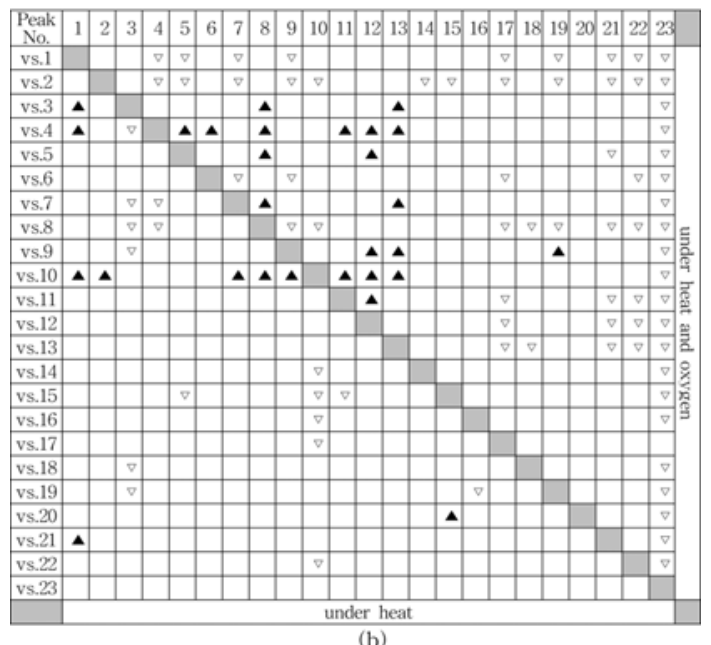

Fig. 6. Changes in the ratios of peak area to the peak area of no. 1 according to the duration of artificial ageing(a) and table showing the trend of all sets of peaks(b). Bottom-left of the table for the trend with heat ageing and up-right for that with heat and oxygen ageing.

3(1-metheyl-2-(1-methylethyl)benzene)의 경우 peak 면 적 총합에 대해 지속적으로 감소하였는데, 개별 성분 과 비교했을 때는 1 (tricyclene), 4 (limonene), 7 (fenchyl alcohol), 8 (camphor), 9 (borneol), 18, 19 (valeric acid) 에 대해 감소하는 경향을 보였다.

산소 열화의 경우 호박의 주요 구성물질로 알려진 23 (abietic acid)에 대해서는 17 (1,1,3,3-tetramethyl1,3,5-trisilacyclohexane)을 제외하고는 모두 증가하였 다. 실제 크로마토그램을 봤을 때 열화가 진행됨에 따 라 23(abietic acid)이 급격하게 감소하면서 이러한 현 상이 나타난 것으로 보인다. 열화가 진행되면서 1 (tricyclene), 2 (camphene), 6 (fenchone), 8 (camphor), 11 (naphthalene류), 12 (anthracene류), 13은 대체적으로 감소하고, 4 (limonene), 5 (benzene류), 7 (fenchyl alcohol), 9(borneol), 10 (butanedioic acid), 17 (trisilacyclohexane), 21 (phenanthrene류), 22 (phenanthrene류)는 상대적으로 증가하는 것으로 보인다. 여기서 7 (fenchyl alcohol)에

Vol. 26, No. 3, 2013 


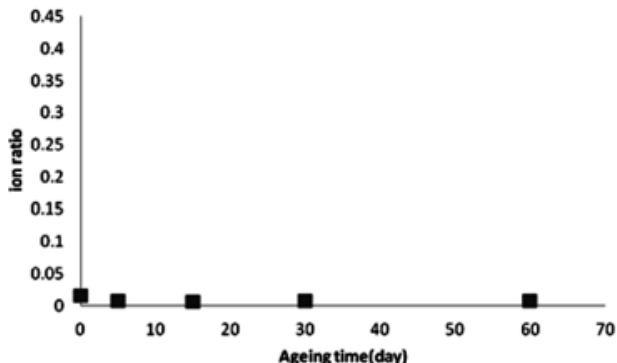

(a)

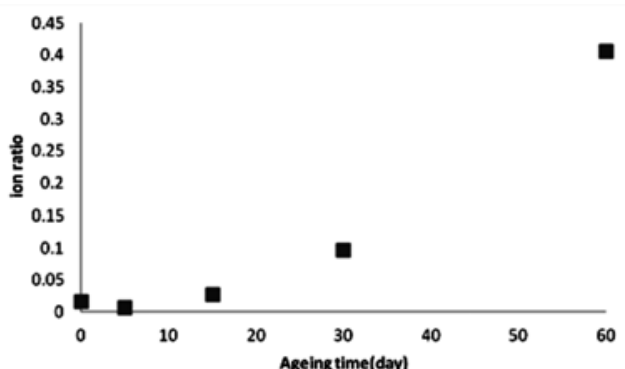

(b)

Fig. 7. Changes in abietic acid according to artificial ageing: (a) under heat, (b) under heat and oxygen. Ion ratio : peak area ratio of $\mathrm{m} / \mathrm{z}=239$ to $\mathrm{m} / \mathrm{z}=241$.

대해서 6 (fenchone)이 증가하는데, fenchyl alcohol이 산화되어 fenchone이 생성됨을 감안할 때 이 반응이 실제 산소열화에서 일어나는 것으로 보인다. 또한, 9 (borneol)에 대해 8 (camphor)이 지속적으로 증가하 는 것도 borneol이 산화되어 camphor가 생성되는 것으 로 설명할 수 있다. 10 (butanedioic acid)은 2 (camphene), 8 (camphor), 11 (1,2,3,4-tetrahydro-1,1,6-trimethylnaphthalene), 12 (1,2,3,4,5,6,7,8-octahydroanthracene), 13 에 대해서는 감소하고, 23 (abietic acid)에 대해서는 증가 하고 있다. abietic acid의 열화산물이 butanedioic acid 라는 보고 ${ }^{19}$ 와 일치하는 결과이다.

한편, abietic acid는 산화되어 dehydroabietic acid 로 변하는 것으로 알려져 있다. 열화에 따른 산화 정 도를 파악하고자 abietic acid(trimethylsilyl ester)와 dehydroabietic acid(trimethylsilyl ester)의 함량비를 열화시간에 대해 플랏하였다(Fig. 7). 여기서 함량비 는 질량스펙트럼에서 주요 이온인 $\mathrm{m} / \mathrm{z}=239$ (dehydroabietic acid) 면적의 $\mathrm{m} / \mathrm{z}=241$ (abietic acid) 면적에
대한 비율이다. 열 열화조건에서는 비율이 약간 감소 하여 5일 후에는 일정한 값을 유지하는 것으로 보아 abietic acid의 산화가 크지 않음을 알 수 있다. 하지 만, 산소가 있는 조건에서는 비율이 열화시간에 비례 하여 급격하게 증가하였는데, 산소가 있는 상황에서 abietic acid가 dehydorabietic acid로 쉽게 산화됨을 알 수 있었다. 이는 abietic acid에 있는 이중결합에서 쉽게 산화반응이 일어난다는 보고와 일치하는 결과 이다. ${ }^{4}$

\section{3. 자연풍화시료와의 비교}

Fig. 8에 호박원석의 내부와 풍화된 표면의 열분해/ $\mathrm{GC} / \mathrm{MS}$ 크로마토그램을 나타냈다. 우선, 풍화가 진행 되더라도 크로마토그램의 패턴은 유지되는 것을 볼 수 있다. 그 중에서 abietic acid는 감소하였고, 나머지 peak는 면적이 증가하였는데, abietic acid가 풍화되면 서 나머지 성분을 생성하는 것으로 보인다. peak 면적 총합에 대한 peak 면적비의 변화를 볼 때 abietic acid
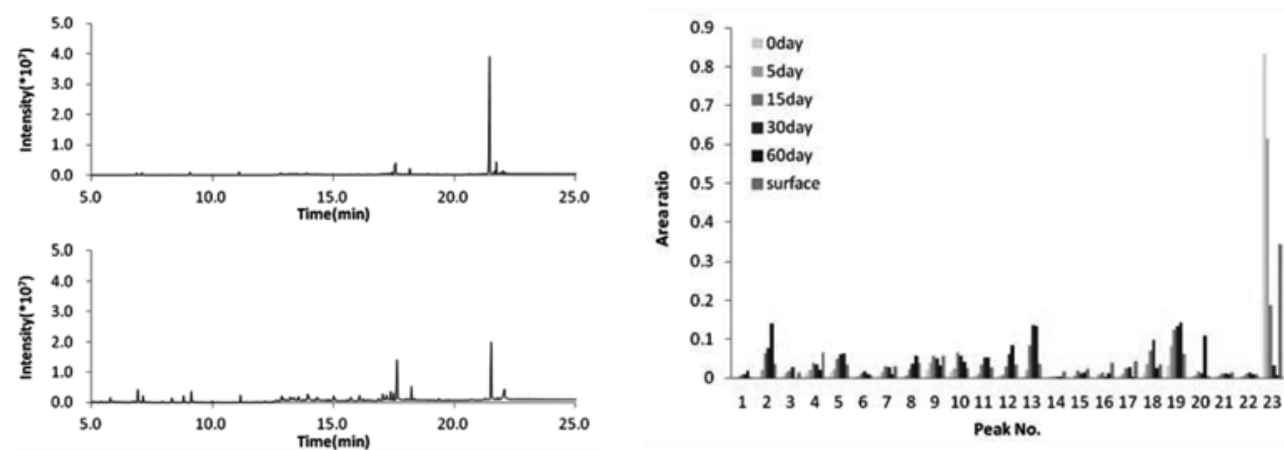

(b)

Fig. 8. py/GC/MS chromatograms of fresh inner part(a, top) and weathered surface(a, bottom) of naturally weathered amber. (b) Changes in the ratio of each peak area to the sum of all peak areas in the chromatograms of ageing under heat and oxygen and that of weathered surface. 
의 변화가 거의 없는 열 열화보다는 열화에 따라 양 이 감소하는 산소열화 조건에 더 가까운데, 자연풍화 에 있어 산소의 역할이 크게 작용한다는 것을 알 수 있다. abietic acid의 비율로 볼 때 산소열화 조건에서 5 15일 경과한 시료와 유사한 함량을 보이고 있으며 기타 성분들도 대략 이 범위에 드는 함량 변화를 보 여 주고 있다. 표면의 abietic acid (trimethylsilyl ester) 에 대한 dehydroabietic acid(trimethylsilyl ester)의 비 율도 0.01 로 산소열화의 5 15일에 해당하는 값을 가 지고 있다.

여기서 한 가지 주의할 점은 크로마토그램에서 우 점하는 성분의 변화가 큰 경우 나머지 성분들이 전체 적으로 감소 또는 증가하는 것으로 관찰돼 경향성을 왜곡할 수 있다는 것이다. 따라서, 한 개의 크로마토 그램에서 각 peak면적 간의 비율을 구하고 그 비율이 다른 크로마토그램에서 증가 또는 감소하는지 관찰한 다면 열화에 따른 변화를 특정성분에 영향 받지 않고 peak 조합에서의 비율변화로 해석할 수 있을 것이다. 이 때 통제된 조건에서 관찰한 이 조합들의 변화 경 향이 활용될 수 있으며, 특히 지속적으로 증가 또는 감소하는 조합을 택해 실제 시료에 적용함으로써 열 화의 상태를 보다 정확하게 정의할 수 있다. 풍화된 표면의 경우 총 253 개 $\left({ }_{23} \mathrm{C}_{2}\right)$ peak 조합 중 앞에서 정 리한 산소열화조건에서 나타난 지속적 증가 또는 감 소 경향에 해당하는 조합(81개)을 따르는 조합이 69개 인 것으로 나타나 경향의 일치율이 $85.2 \%$ 로 나타났다. 따라서, 풍화된 표면이 열과 산소 열화 조건에서 열화 했을 가능성이 높으며, 앞에서 본 것처럼 abietic acid 가 열 열화의 경향성과는 크게 다름을 감안했을 때, 산소의 영향을 많이 받은 것으로 보인다. 한편, 산소 열화의 경향성을 따르는 조합 $(1,5),(1,9),(1,19),(1,21)$, $(1,22),(1,23),(2,4),(2,5),(2,7),(2,9)$ 등 69 개에 대해 열화시간에 따른 변화 정도를 정량적으로 분석하고, 이를 다양한 풍화시료에 적용하여 검증을 한다면 호 박의 풍화상태를 진단할 수 있는 마커로 활용할 수 있을 것으로 기대된다.

\section{4. 결 론}

1. 호박을 열분해/GC/MS로 분석한 결과 abietic acid 가 주성분으로 검출되었으며, valeric acid, butanedioic acid, borneol, aromatic hydrocarbon 등이 주요하게 검 출되었다.

2. 60 일 동안 산소조건과 열 조건에서 인공열화한
호박과 자연풍화 호박의 열분해/GC/MS 크로마토그램 이 열화전 호박의 크로마토그램과 유사하게 유지되고 있어 풍화상태의 호박을 확인하는데 이 방법이 유용 할 것으로 보인다.

3. 23 개 성분의 함량변화를 peak 면적 총합과 각 peak 면적에 대한 비율로 각각 관찰한 결과 산소조건 에서 열화시킨 호박에서 변화가 크게 나타났고, 열화 기간에 따라 peak 면적비의 지속적 변화가 있는 성분 조합을 찾을 수 있었다.

4. 자연풍화시료의 성분변화는 산소조건에서 열화한 시료와 유사한 경향성을 보여 산소가 호박의 자연풍 화에 중요한 역할을 함을 알 수 있었고, 면적비 변화 를 이용할 경우 호박의 열화상태를 가늠할 수 있을 것으로 판단된다.

\section{참고문헌}

1. J. Park and Y. Lim, J. Conserv. Sci., 28(3), 247-256 (2012).

2. E. Barletta and K. Wandelt, J. Non-cryst. Solids, 357, 1473-1478 (2011).

3. D. Grimaldi, Sci., 326, 51-52 (2009).

4. D. Scalarone and O. Chiantore, In 'Organic mass spectrometry in art and archaeology', M. P. Colombini and F. Modugno Eds., p327, Wiley, West Sussex, 2009.

5. Y. Shashoua, 'Degradation and inhibitive conservation of Baltic amber in museum collections', The National Museum of Denmark, 2002.

6. K. L. Sobeih, M. Maron and J. Gonzalez-Rodriguez, $J$. Chromatogr. A, 1186, 51-66 (2008).

7. L. Osete-Cortina and M. T. Doménech-Carbó, J. Chromatogr. A, 1065, 265-278 (2005).

8. L. Osete-Cortina and M. T. Doménech-Carbó, J. Chromatogr. A, 1127, 228-236 (2006).

9. H. Ling, N. Maiqian, G. Chiavari and R. Mazzeo, Microchem. J., 85, 347-353 (2007).

10. M. J. Casas-Catalán and M. T. Doménech-Carbó, Anal. Bioanal. Chem., 382, 259-268 (2005).

11. I. Bonaduce and M. P. Colombini, J. Chromatogr. A, 1028, 297-306 (2004).

12. M. Guiliano, L. Asia, G. Onoratini and G. Mille, Spectrochimica Acta Part A, 67, 1407-1411 (2007).

13. R. H. Brody, H. G. M. Edwards and A. M. Pollard, Spectrochimica Acta Part A, 57, 1325-1338 (2001).

Vol. 26, No. 3, 2013 
14. J. Park, Y. Lim, 'Study on the characteristics of archaeological amber', National Research Institute of Cultural Heritage, 2011.

15. J. Park and Y. Lim, Anal. Sci. Technol., 24(4), 256-265 (2011).

16. J. P. Lewicki, R. L. F. Albo, C. T. Alviso and R. S.
Maxwell, J. Anal. Appl. Pyrol., 99, 85-91 (2013).

17. D. W. Page, J. A. van Leeuwen, K. M. Spark and D. E. Mulcahy, J. Anal. Appl. Pyrol., 67, 247-262 (2003).

18. D. Scalarone, M. Lazzari and O. Chiantore, J. Anal. Appl. Pyrol., 58-59, 503-512 (2001).

19. R. C. A. Rottlaender, Archaeometry, 12, 35-52 (1970). 